\title{
The Role of Vascular Endothelial Growth Factor in Wound Healing
}

\author{
Philip Bao, MD ${ }^{1}$, Arber Kodra, BA ${ }^{2}$, Marjana Tomic-Canic, PhD ${ }^{3}$, Michael S. Golinko, MD ${ }^{4}$, \\ H Paul Ehrlich, PhD $^{5}$, and Harold Brem, MD ${ }^{4}$ \\ ${ }^{1}$ University of Pittsburgh, Department of Surgery, Pittsburgh, PA \\ 2 New York Medical College, Valhalla, NY \\ ${ }^{3}$ Hospital for Special Surgery, Tissue Engineering, Regeneration \& Repair Program New York, New \\ York
}

${ }^{4}$ New York University School of Medicine, Department of Surgery, Division of Wound Healing \& Regenerative Medicine, New York, NY

${ }^{5}$ Division of Plastic Surgery, Pennsylvania State Medical Center, Hershey, PA

\section{Introduction}

The term "chronic wound" describes a wound that occurs in a patient who has physiologic impairments to healing (Table 1). These pathophysiologic processes predispose cutaneous wounds to deviate from the characteristics of acute wound healing. Although a chronic wound is not always slow to heal, it should be considered "emergent" in that it is often a non-healing wound. An estimated 3 to 6 million chronic skin ulcers occur in patients every year in the United States. The most common underlying conditions are venous reflux, pressure, and diabetes mellitus $1,2,3,4,5$

In the vast majority of surgical procedures, nearly all acute wounds heal by an orderly and timely process ${ }^{6}$, with a strength and integrity similar to normal skin. ${ }^{7,8}$ Wounds refractory to moist healing, however, may be candidates for growth factor therapy, which is assumed to stimulate missing or dysfunctional components of the chronic wound ${ }^{9-11}$. An angiogenic growth factor may promote closure of chronic wounds exhibiting hypoxia and compromised vascularity.

Vascular endothelial growth factor (VEGF) is one such candidate. It functions as an endothelial cell mitogen ${ }^{12-17}$, chemotactic agent ${ }^{18}, 19$, and inducer of vascular permeability $20,21,22-$ 26. Other angiogenic growth factors such as basic fibroblast growth factor (bFGF) and transforming growth factor $\beta$ (TGF- $\beta$ ) have been described, but VEGF is unique for its effects on multiple components of the wound healing cascade, including angiogenesis and recently shown epithelization and collagen deposition. ${ }^{27}$. Purified growth factors ${ }^{28}$ and cultured human cells ${ }^{29-31}$ have both been approved by the Food and Drug Administration to accelerate closure of non-healing wounds. This has transformed the field of wound healing by establishing the efficacy of a topical growth factor and cell therapy. Since angiogenesis maintains a critical role

\footnotetext{
Address for reprints \& corresponding author: Harold Brem, MD FACS, Chief, Division of Wound Healing \& Regenerative Medicine, Department of Surgery, NYU School of Medicine, 462 First Avenue, NBV 15W16, New York, NY 10016, Cell : 917-572-7014, Fax: 212-658-9806, Harold.brem@nyumc.org.

Publisher's Disclaimer: This is a PDF file of an unedited manuscript that has been accepted for publication. As a service to our customers we are providing this early version of the manuscript. The manuscript will undergo copyediting, typesetting, and review of the resulting proof before it is published in its final citable form. Please note that during the production process errors may be discovered which could affect the content, and all legal disclaimers that apply to the journal pertain.
} 
in wound healing, in the future, VEGF (alone or in combination therapy) may be utilized on patients with nonhealing wounds. This review the role of angiogenesis by VEGF in wound healing.

\section{Structure and Heterogeneity}

VEGF is a homodimeric glycoprotein that shares almost $20 \%$ amino acid homology with platelet derived growth factor (PDGF) ${ }^{16}$. VEGF exists in five isoforms resulting from alternative splicing of its mRNA, with chain lengths of 121, 145, 165, 189, and 206 amino acids ${ }^{32-35}$. These 5 forms are commonly referred to as VEGF-A ( VEGF $_{165}$ ) VEGF-B, VEGF$\mathrm{D}$ and placental growth factor (PIGF). In addition, VEGF_-C has been shown to be secreted by macrophages and their role in wound healing has begun to be investigated. ${ }^{36}$ As the chain length increases, VEGF changes from a weakly acidic to a basic form, which enhances the ability of the molecule to bind heparin at its carboxy terminus. Conversely, the amino terminus of VEGF contains a signal sequence for protein secretion ${ }^{15}$. The bioavailability of VEGF depends upon its isoform, where $\mathrm{VEGF}_{121}$ is freely secreted, and where $\mathrm{VEGF}_{189}$ and VEGF $_{206}$ are secreted, but largely bound to heparin residing on cell surfaces. VEGF 145 and $\mathrm{VEGF}_{165}$ isoforms show intermediate characteristics, with equally bound and free forms. The balance of free versus bound VEGF has important implications for systemic versus local effects. VEGF 165 is the most studied and available isoform and this review of VEGF will refer to this isoform exclusively.

\section{Synthesis and Receptors}

\section{Cells in a healing wound synthesize VEGF}

VEGF is produced by many cell types that participate in wound healing: endothelial cells 37 , ${ }^{38}$, fibroblasts ${ }^{39}$, smooth muscle cells ${ }^{40,}{ }^{41}$, platelets ${ }^{42}$, neutrophils ${ }^{43}$, and macrophages ${ }^{44}$. The dominant isoform of VEGF is the shorter variant, which is soluble in the extracellular space.

\section{VEGF receptors}

In humans, VEGF binds with receptors Flt-1 (VEGFR-1) and KDR (VEGFR-2), both high affinity receptors ${ }^{45-47}$. They are members of the Type III tyrosine kinase family, consisting of seven immunoglobulin-like extracellular domains, a single transmembrane spanning domain, and an intracellular tyrosine kinase domain. Two additional receptors have been designated low affinity/molecular mass VEGF receptors, but their structure and function are not well characterized ${ }^{48}$.

KDR and Flt- 1 are localized to the endothelial surface of developing and mature blood vessels $49-51$. KDR and Flt- 1 are only $37 \%$ and $45 \%$ homologous in their extracellular and kinase domains, respectively ${ }^{52}$. Mutational mouse studies of VEGF receptor genes have shown that Flk-1, the mouse homologue of KDR, is important for endothelial cell differentiation, whereas Flt-1 is required for organization of blood vessels 53,54 . VEGF induces membrane ruffling, chemotaxis and proliferation in endothelial cells expressing only KDR, but not in those exclusively expressing Flt- ${ }^{55}$. KDR mediates the mitogenic and chemotactic activities of VEGF. The roles of Flt-1 are less certain, but its functions may include the mediation of vascular permeability ${ }^{56}$, the chemotactic response of neutrophils and macrophages ${ }^{57}$, the expression of matrix metalloproteinases in vascular smooth muscle cells ${ }^{58}$, and the induction of anti-apoptotic proteins ${ }^{59}$.

A third tyrosine kinase receptor VEGFR3 (Flt-4) has also been characterized. ${ }^{60,} 61$ Since that time, this receptor has been shown to mediate primarily lymphangiogenesis. ${ }^{62,63}$ 


\section{VEGF Stimulates Multiple Components of the Angiogenic Cascade}

One of VEGF's roles in wound healing is in stimulation of angiogenesis. Wound healing angiogenesis involves multiple steps including vasodilation, basement membrane degradation, endothelial cell migration, and endothelial cell proliferation ${ }^{64}$. Subsequently, capillary tube formation occurs, followed by anastomosis of parallel capillary sprouts (loop formation), and finally new basement membrane formation. VEGF plays a role in several of these processes (Figure 1).

\section{Vasodilation}

A unique property of VEGF is its ability to increase vascular permeability ${ }^{65}$. Before its amino acid sequence was known, VEGF was designated vascular permeability factor (VPF). VEGF is more potent than histamine in inducing vascular leakage ${ }^{17,20,21}$. It binds to the KDR receptor, stimulating nitric oxide synthase (NOS) and cyclooxygenase activities ${ }^{65}$. NO and prostacyclin promote simultaneous vasodilation and vascular permeability 66,67 . Vasodilation and accompanying stretch may also increase endothelial sensitivity to growth factors ${ }^{64}$, as well as induce further VEGF expression in a positive feedback loop 68 .

\section{Degradation of basement membrane}

VEGF induces procoagulant factors in endothelial cells, such as Von Willebrand Factor, which mediates platelet adhesion and aggregation ${ }^{69}$. Platelets themselves synthesize and release VEGF $^{42}$, thereby increasing local concentration of protein, activating the coagulation cascade and the ultimate generation of thrombin and fibrin. Thrombin activates endothelial progelatinase A. VEGF directly increases endothelial cell secretion of interstitial collagenase (MMP-1), tissue inhibitor of metalloproteinases (TIMP-1), and gelatinase A (MMP-2) ${ }^{70}$. VEGF also induces dose-dependent expression of urokinase-type and tissue-type plasminogen activator (uPA and tPA) as well as plasminogen activator inhibitor-1 (PAI-1) ${ }^{71}$. In addition, VEGF stimulates vascular smooth muscle cells to express MMP-1, MMP-3, and MMP-9 ${ }^{58}$.

The local vascular environment induced by VEGF represents a balance of enzymatic promoters and inhibitors, setting the stage for endothelial migration. MMP-2 may degrade Type IV collagen, a constituent of vascular basement membranes. MMP-1 breaks down collagen types I-III ${ }^{70}$. Plasmin cleaves the heparin-binding carboxy termini of VEGF isoforms 165,189 , and 206 , releasing their active soluble forms ${ }^{34}$. Consequently, enzymatic activity can promote further VEGF release. The resultant proteolytic environment destroys structural elements of the basement membrane and extracellular matrix, facilitating endothelial movement into the extravascular space.

\section{Endothelial cell migration}

VEGF induces endothelial cell migration in wound healing through two primary mechanisms, chemotaxis and vasodilatation. In the initial phase of angiogenesis, endothelial cells migrate before mitotic division ${ }^{18}$. Capillary budding may also be sustained for up to 4 or 5 days by endothelial elongation and migration without proliferation. How VEGF stimulates endothelial cell migration is detailed below.

Mechanism I: Chemotaxis-Chemotaxis is a highly regulated process involving cell adhesion molecules' interaction with the extracellular matrix. VEGF-induced angiogenesis in the rabbit cornea and chick chorioallantoic membrane involved participation of $\alpha_{\mathrm{v}} \beta_{5}$ integrin [64]. VEGF also induces expression of uPA, which is required for $\alpha_{v} \beta_{5}$-directed endothelial cell migration on vitronectin, ${ }^{72}$ In vitro models, however, demonstrate that VEGF enhances not only the expression of the $\alpha_{\mathrm{v}} \beta_{5}$ integrin but also that of the $\alpha_{\mathrm{v}} \beta_{3}$ integrin ${ }^{73,74}$. Furthermore, VEGF induces osteopontin (OPN), an $\alpha_{\mathrm{v}} \beta_{3}$ ligand, and both OPN and thrombin-cleaved OPN 
are chemotactic for dermal endothelial cells ${ }^{74}$. The role of these integrins and whether VEGF is selective for a specific integrin pathway during angiogenesis and wound healing remain a promising area of study.

Mechanism II: Increasing vascular permeability-Another mechanism by which VEGF induces endothelial cell migration in wound healing is related to the increase in vascular permeability mediated by $\mathrm{NO}$ and prostacyclin. Leakage of the plasma protein fibrinogen and its subsequent conversion in the extracellular space to a fibrin gel stimulates endothelial migration.

\section{Endothelial cell proliferation}

VEGF is described as a mitogen selective for endothelial cells. It is unclear which molecules transduce the mitogenic signal, but NO and cGMP appear to be involved ${ }^{75}$. VEGF induces endothelial cells grown on the surface of a collagen matrix to invade the underlying matrix ${ }^{76}$, and stimulates their proliferative response ${ }^{77}$.

Furthermore, VEGF delays senescence and restores proliferative capacity to endothelial cells ${ }^{78}$. It lengthens the life span of endothelial cells and prevents apoptosis by inducing the transient expression of two anti-apoptotic proteins in human endothelial cells ${ }^{79}$. These proteins may be responsible for VEGF's prevention of apoptosis, induced by TNF- $\alpha$ in endothelial cells and by ionizing radiation in hematopoietic stem cells 59,80 .

VEGF may also mediate the survival effect by maintaining cell attachment through stimulation of fibronectin and $\beta_{3}$ integrin expression ${ }^{80}$. Similarly, VEGF inhibits apoptosis in cells cultured on non-supportive, hydrophobic surfaces, but this involves increased expression of $\alpha_{\mathrm{v}} \beta_{5}$ integrin and deposition of vitronectin ${ }^{81}$. Inhibition of apoptosis also is also achieved through inhibition of pro-apoptotic signaling, including forkhead (FKHR) ${ }^{82}$ or activation of caspase- $3{ }^{83}$ Thus, the increased replication and increased absolute life-span of endothelial cells augments VEGF-induced proliferation. In addition, the proliferative and anti-apoptotic properties of VEGF have been shown to be partially mediated either MAP2K1/2/MAPK3/1 and PI3K/AKT1 pathways. ${ }^{79,84,85} 86$ with subsequent inhibition of pro-apoptotic signaling. 82

\section{VEGF and Wound Healing}

An essential feature of normal wound repair is the formation of granulation tissue, i.e. fibrovascular tissue containing fibroblasts, collagen and blood vessels, which is the hallmark of an established healing response. The vascular component depends upon angiogenesis, in which new vessels appear as early as day 3 after wounding ${ }^{87}$. Capillary growth into the wound subsequently provides a conduit for nutrients and other mediators of the healing response as well as removal of metabolites. Inhibition of angiogenesis impairs wound healing $88,89,90$.

\section{Early cells in a healing wound synthesize and release VEGF}

Various cellular responses to a wound involve the release of VEGF. The platelet is the first vascular component to appear in the wound site, followed by neutrophils, and then macrophages ${ }^{87}$. Activated platelets release VEGF, particularly after thrombin stimulation ${ }^{42}$, 91.

Monocytes play both a direct and indirect role in the angiogenic effects during wound healing. Monocytes express the VEGF receptor Flt- 1 and respond chemotactically to VEGF ${ }^{52}$. Once recruited to the tissue, macrophages induce angiogenesis, in part by releasing TNF- $\alpha$, which may in turn induce VEGF expression in keratinocytes and fibroblasts ${ }^{92-94}$. 
Cells involved in healing release cytokines and growth factors that may act as paracrine factors for further VEGF expression (Table 2). Factors that induce VEGF transcription and secretion include: TGF- $\beta 1$, EGF, TGF- $\alpha$, and KGF (from keratinocytes ${ }^{93}$ and arterial smooth muscle cells ${ }^{40}$ ) and bFGF, PDGF-BB, and IL-1 $\beta$ (from aortic smooth muscle cells ${ }^{41}$ ).

\section{Hypoxia induces VEGF}

Metabolic derangements of the wound environment upregulate VEGF. Ischemia and hypoxia are characteristic of tissue damage, where oxygen tension in the wound is 6-7 $\mathrm{mmHg}$ after 5 days, compared to normal tissue levels of $45-50 \mathrm{mmHg} 95,96$. Angiogenesis restores tissue perfusion, reestablishes microcirculation, and increases oxygen tension to $30-40 \mathrm{mmHg} 96$. Thus, hypoxia enhances VEGF expression in monocytes as well as a variety of other cell types, including fibroblasts, keratinocytes, myocytes, and endothelial cells ${ }^{38,97-99}$. Adenosine has been shown to mediate this hypoxic response 100,101 , and subsequent transduction pathways increase both VEGF mRNA transcription and half-life ${ }^{102-104}$.

Similarly, hypoxia stimulates Flt-1 receptor expression on cultured endothelial cells 97 . Hypoxic cultures acutely downregulate KDR expression, rendering it undetectable after 24 hours. Long-term exposure to hypoxia for 72 hours, however, results in KDR reception ${ }^{97}$, 101 .

Hypoxia upregulates tissue expression of VEGF and its receptors, which in turn promote an angiogenic response. Hypoxia, through hypoxia inducible factor (HIF)-1alpha, induces the expression of VEGF ${ }^{105,106}$ A gradient of VEGF expression is established that parallels the hypoxic gradient, and endothelial cells subsequently migrate towards the most hypoxic areas. Macrophages help maintain the gradient, as they can survive in areas with the lowest oxygen tensions ${ }^{96}$. Indeed, a hypoxic tissue gradient is mandatory for wound healing-related angiogenesis, and removal of that gradient inhibits capillary growth ${ }^{107}$.

\section{VEGF presents in wounds in a specific temporal pattern}

VEGF transcription and secretion are elevated in partial 108 and full thickness skin wounds 93, 109. In partial thickness wounds, keratinocytes at the wound edge express elevated VEGF as early as 1 day after injury and eventually in those cells, which migrate to cover the defect. Epidermal labeling for VEGF mRNA reaches a peak after 2-3 days, coincident with a peak in vascular permeability, and levels remain elevated until epidermal coverage is complete. Likewise, maximal VEGF mRNA is found between 3 and 7 days after full-thickness wounding, during the period of granulation tissue formation ${ }^{93}$. In these deeper wounds, VEGF is localized primarily to fibroblasts and macrophages ${ }^{39}$. A corresponding increase in Flt-1 expression occurs in dilated vessels bordering the wound at 3 days, and within the wound at 7 days postinjury ${ }^{50}$. Similarly, MMP-1, MMP-2, and TIMP-1, each inducible by VEGF, peak 2 to 5 days after excisional wounding ${ }^{110}$.

The time course of VEGF expression provides insight into the progression of wound healing. During the proliferative phase of repair occurring approximately 3 to 7 days post-wounding capillary growth and differentiation are at a maximum. During this period, VEGF is upregulated to promote the early stages of angiogenesis (i.e., vascular dilation, permeability, migration, and proliferation). ${ }^{39}$. Antibody neutralization of VEGF diminishes the chemotactic and angiogenic properties of wound fluid, thus revealing further evidence for the importance of VEGF in wound repair ${ }^{39}$.

In contrast to the VEGF, basic fibroblast growth factor (bFGF) may be an initial stimulus for angiogenesis, because elevated levels are found immediately in surgical wound fluid, but decline to serum levels by day $3{ }^{39,111}$. This is consistent with sequestration of preformed 
bFGF in normal tissue and its release from cellular and interstitial sites ${ }^{64,112}$. Significant expression of bFGF in wound tissue, however, begins approximately 8 days after full thickness wounding, and peaks at $12-14$ days ${ }^{113}$.

Given these data, a temporal model for angiogenesis during cutaneous wound healing may be described. Preformed bFGF is released upon injury, possibly helping to initiate VEGF expression from nearby vascular smooth muscle and endothelial cells, especially in combination with hypoxia ${ }^{41,114}$. It may also promote a proteolytic environment needed for angiogenesis, as neutralization of bFGF blocks VEGF-induced uPA and tPA expression as well as angiogenesis ${ }^{115}$.

As basic fibroblast growth factor (bFGF) declines, a surge in VEGF from epidermal cells and macrophages induces and maintains early angiogenic steps by the $2^{\text {nd }}$ or $3^{\text {rd }}$ day after wounding. The influence of VEGF diminishes when inducers of VEGF like hypoxia decrease, or when factors like bFGF predominate in regulating the later stages of angiogenesis, such as lumen formation and basement membrane development. Accordingly, VEGF declines to basal levels after 1 week, just as bFGF begins its second increase, due to the numbers of endothelial cells and fibroblasts expressing bFGF. This model may explain in part the observed action between VEGF and bFGF, such that each is critical to early and late angiogenic steps, respectively.

Integrins associated with VEGF activity follow a similar pattern of expression in wound healing. In full thickness wounds at days 3 and $4, \alpha_{v} \beta_{3}$ integrin is localized on hypertrophied vessels at the wound margin as well as on the tips of capillary sprouts invading the fibrin clot. Expression of $\alpha_{\mathrm{v}} \beta_{3}$ disappears by day 7, as VEGF returns to baseline levels ${ }^{116}$. Inhibition of granulation tissue formation and angiogenesis by neutralization of $\alpha_{\mathrm{v}} \beta_{3}$ emphasizes the importance of this integrin to wound healing 116,117 .

In summary, direct and indirect evidence implicates VEGF as a significant factor in wound healing immediately after injury. Induced by inflammatory cells and local wound conditions, VEGF potentially alleviates tissue hypoxia and metabolic deficiencies by promoting early events in angiogenesis, as well as endothelial cell function. Maximal activity occurs during a "window" period approximately 3 to 7 days after injury. Once the wound is granulated, angiogenesis ceases and blood vessels decline as endothelial cells undergo apoptosis. The reduction in VEGF and the loss of apoptosis may contribute to this transition from hypercellular granulation tissue to a hypocellular scar. A theoretical but clinically relevant side effect of topical VEGF therapy may be the development of a hypertrophic scar, though this has not been reported.

\section{Surgical Applications of VEGF and Therapeutic Angiogenesis Clinical use of VEGF in humans}

Phase I clinical trials have been initiated for patients with nonspecific limb ischemia ${ }^{118,}{ }^{119}$, Buerger's disease ${ }^{120}$, and myocardial ischemia ${ }^{121}$. As early as 1996 , balloon transfer of plasmid DNA expressing VEGF $_{165}$ was attempted on a non-diabetic patient with arterial occlusive disease in the lower extremity ${ }^{118}$. Following gene transfer to the distal popliteal artery, collateral vessels, and flow to the leg were increased, and the site of transfer did not show intimal thickening. Although limb gangrene could not be reversed and the limb was eventually amputated, the experiment confirmed the feasibility of therapeutic angiogenesis for humans. The only reported adverse events were three spider angiomas, which resolved, and peripheral edema in the treated leg, which was successfully treated with diuretics. More recently, intramuscular gene transfer of $\mathrm{VEGF}_{165}$ to 9 patients with ischemic ulcers and/or rest pain secondary to peripheral arterial disease resulted in limb salvage for 3 and significantly decreased rest pain for all patients ${ }^{119}$. The only complication observed was transient edema in the treated lower extremities. With a similar experimental protocol, positive results have 
also been demonstrated in patients with advanced Buerger's disease ${ }^{120}$. VEGF can partially reverse the ischemia of coronary heart disease. Plasmid-encoded VEGF injected directly into the myocardium of patients for whom conventional therapy for angina had failed resulted in a reduction of symptoms with improved coronary vasculature ${ }^{121}$. VEGF has shown positive and safe results administered alone or as adjunctive therapy to angioplasty and surgery ${ }^{122-}$ ${ }^{124}$. An additional benefit in angioplasty may be secondary to prevention of restenosis in manipulated vessels.

\section{Other conditions that may benefit from VEGF therapy}

There exist several clinical situations in which paucity of cellular mediators impairs wound healing. For example, dermal wounds of peripheral vascular disease patients mature more slowly and display fewer neutrophils and macrophages ${ }^{125}$. Wounds with transcutaneous oxygen pressures $\left(\mathrm{TcPO}_{2}\right)$ of less than $20 \mathrm{mmHg}$ are slower to mature and patients with such wounds are more likely to have ulcers, rest pain, and amputation ${ }^{126}$. Furthermore, wound hypoxia limits neutrophil bactericidal activity and predicts infection in surgical patients ${ }^{127}$, 128. Therefore, VEGF may enhance and activate mononuclear cells and accelerate closure of nonhealing skin ulcers.

\section{Diabetic foot ulcers and VEGF}

Diabetes is the prototypical model of impaired wound healing. Patients with diabetes have decreased rates of tissue repair associated with low periwound $\mathrm{TcPO}_{2}$ and blood pressure ${ }^{129}$. Notably, capillary density is reduced in the muscles of patients with non-insulin dependent diabetes ${ }^{130}$. The predisposition to ulceration in persons with diabetes has multifactorial and interrelated causes, including endothelial dysfunction, atherosclerosis, and peripheral neuropathy.

Multiple metabolic disturbances may be responsible for endothelial dysfunction, including oxidative stress, hyperglycemic pseudohypoxia, nonenzymatic glycation, and activation of the coagulation cascade ${ }^{131}, 132$.

If the diabetic milieu favors VEGF expression, how is VEGF involved in the pathophysiology of diabetic wound healing? In accordance with this model, VEGF mRNA is elevated in the non-wounded skin of genetically diabetic mice. However, upon full-thickness excisional wounding, VEGF levels initially increase but eventually decrease to undetectable levels by day 5. During this time period granulation tissue is accumulating and VEGF peaks in nondiabetic, normal tissue ${ }^{93}$. Additionally, wounds of streptozotocin-induced diabetic mice demonstrate diminished synthesis of several growth factors, including VEGF ${ }^{109}$. In an ischemic hindlimb model of non-obese diabetic mice, impaired neovascularization is accompanied by diminished levels of VEGF mRNA and protein ${ }^{133}$. Finally, an acute drop from an elevated glucose concentration, which is an expected occurrence with diabetes, does not induce VEGF ${ }^{134}$. A discussion of why VEGF is not elevated in chronic wounds is outside the scope of this review. However, one can state that a defect in growth factor regulation is observed in diabetic wounds despite systemic and local conditions that actually favor their expression.

Healing of full-thickness wounds is intrinsically different in diabetic animals. Diabetic wounds tend to heal by cellular infiltration, deposition of granulation tissue, and reepithelialization, not by contraction, as occurs in wounds of normal animals. This pattern of wound closure is common to the tissue of chronic ulcers in patients with diabetes decubitus ulcers, and venous stasis ${ }^{135}$. Application of VEGF to a diabetic wound may enhance healing by promoting chemotaxis and angiogenesis. In addition, one of the mediators of VEGF activity, NO, enhances collagen deposition in diabetic wounds and may restore endothelial function to 
improve both nerve conduction and tissue oxygenation. In addition, new experimental data suggests that VEGF stimulates epithelization and collagen production ${ }^{27,136}$.

Consistent with its multiple mechanisms, VEGF may promote healing on multiple levels. Although PDGF is efficacious in diabetic ulcers ${ }^{137}$, VEGF may stimulate additional components of wound healing independently of PDGF. VEGF alone or in combination with other treatment modalities may prove to be an effective treatment for diabetic vascular disease and ulcers. This possibility has recently been confirmed by the demonstration that gene therapy with VEGF restores the impaired angiogenesis found in ischemic limbs of diabetic mice ${ }^{133}$. Further rigorous study is needed to test the hypothesis that VEGF may be useful for treatment of pressure ulcers and diabetic foot ulcers.

\section{Venous stasis}

The role of VEGF in chronic wounds secondary to venous insufficiency is also complex. Ulceration is thought to result from the accumulation and inappropriate activity of leukocytes 138,139 . The release of cytokines, including TNF- $\alpha$ promotes excess deposition of a fibrin cuff around capillaries, which causes a barrier to oxygen diffusion and possibly cell migration. Long-term consequences of leukocyte activity include endothelial dysfunction, interstitial edema, microthrombi, and decreased capillary density. Hence, some degree of tissue hypoxia may be expected to impair wound healing. There is also an imbalance in the proteolytic environment of such wounds, with an overall elevation in matrix metalloproteinases and deficiency in their inhibitors ${ }^{140-142}$.

Given the hypoxic pathologic environment of venous ulcers, plasma and tissue levels of VEGF are increased in patients with venous insufficiency, particularly those with ulcers. ${ }^{143}, 144$ However, the functional level or presence of VEGF and its receptors at the wound site is unknown, and it is uncertain whether chronic venous wounds display a defect in angiogenesis. It might be expected that exogenously administered VEGF would improve perfusion and hence, oxygenation, via angiogenesis. Moreover, VEGF may play a further role in epithelization and collagen deposition if the presumed hypothesis regarding multiple nonangiongenic mechanisms is correct.

\section{Pressure ulcers}

Decreased blood flow to the sacral areas is thought to contribute to the formation of pressure ulcers. Both low resting systolic pressure ${ }^{145}$ and immobility leading to sustained external pressure ${ }^{146}$ produce local skin ischemia in patients at risk for pressure ulcers (i.e., the elderly and persons recovering from spinal cord injury ${ }^{147}$ ). Loss of vasomotor control also contributes to poor perfusion ${ }^{148}$. Pressure ulcers have been treated successfully in randomized trials with the use of topically applied bFGF 149,150 . Thus, angiogenic therapy may be a useful adjunct to pressure relief and skin care, once a wound has developed. Currently, no data exist for the efficacy of VEGF in pressure ulcer healing.

\section{Conclusions}

VEGF stimulates wound healing via multiple mechanisms including collagen deposition, angiogenesis and epithelization. In the clinical setting, the mitogenic, chemotactic, and permeability effects of VEGF may potentially aid to promote repair in nonhealing wounds in arterial occlusive disease and diabetes. It may also alleviate the "wound" of ischemic heart disease. By promoting angiogenesis, VEGF improves tissue perfusion. Sustained release of VEGF ( through ADV gene, biodegradable polymer, fibrin mesh etc..) should be tested as rapidly as possible in patients with DFU's and pressure ulcers. 
An important theme throughout this discussion has been the necessity of understanding the pathophysiology of chronic wounds. The distinct physiologic impairments explain why a wound is slow to heal. The meaningful questions to ask when considering VEGF therapy are: 1 ) is there a deficiency in angiogenesis or improper vascular function? 2) is there a deficiency or dysregulation of VEGF, its receptors, or VEGF signal transduction? and 3) can VEGF therapy provide a positive effect? 4) to what extent is VEGF involved in epithelization and collagen deposition? 5) Ultimately, can VEG reverse any of these physiologic impairments?

Complete understanding of wound pathophysiology and endogenous VEGF expression may help promote exogenous VEGF therapy for the closure of non-healing wounds. Gene transfer studies have demonstrated the clinical efficacy of VEGF and the development of a humangrade protein will further clarify its role. PDGF is the only growth factor currently approved to treat wounds. The addition of VEGF, alone or in combination with other growth factors, may represent a significant step in the medical treatment of nonhealing wounds and other ischemic processes. VEGF may also have a future role as adjunctive therapy to accelerate healing and prevent complications in surgical revascularization, anastomoses, and plastic surgery.

\section{Acknowledgments}

Financial support through: National Institute of Health 5K08DK059424

\section{References}

1. Amlung SR, Miller WL, Bosley LM. The 1999 National Pressure Ulcer Prevalence Survey: a benchmarking approach. Advances in skin \& wound care 2001;14:297-301. [PubMed: 11794440]

2. Hospitalizations Related to Pressure Sores, 2003. Agency for Healthcare Research and Quality; 2006 [Accessed 8/31/2006, 2006]. at http://www.hcup-us.ahrq.gov/reports/statbriefs/sb3.pdf.)

3. Coon WW, Willis PW 3rd, Keller JB. Venous thromboembolism and other venous disease in the Tecumseh community health study. Circulation 1973;48:839-46. [PubMed: 4744789]

4. Diabetes Care; Consensus Development Conference on Diabetic Foot Wound Care; 7-8 April 1999; Boston, Massachusetts. American Diabetes Association; 1999. p. 1354-60.

5. Calle-Pascual A, Garcia-Torre N, Moraga I, et al. Epidemiology of nontraumatic lower-extremity amputation in area 7, Madrid, between 1989 and 1999: a population-based study. Diabetes Care 2001;24:1686-9. [PubMed: 11522722]

6. Strauss MB, Aksenov IV. Evaluation of diabetic wound classifications and a new wound score. Clinical orthopaedics and related research 2005;439:79-86. [PubMed: 16205143]

7. Ho DQ, Bello YM, Grove GL, et al. A pilot study of noninvasive methods to assess healed acute and chronic wounds. Dermatol Surg 2000;26:42-9. [PubMed: 10632685]

8. Li J, Chen J, Kirsner R. Pathophysiology of acute wound healing. Clinics in dermatology 2007;25:918. [PubMed: 17276196]

9. Carter K. Growth factors: the wound healing therapy of the future. British journal of community nursing 2003;8:S15-6. S8-9, S22-3.

10. Debus ES, Schmidt K, Ziegler UE, Thiede A. [The role of growth factors in wound healing]. Zentralblatt fur Chirurgie 2000;125 (Suppl 1):49-55. [PubMed: 10929647]

11. Grazul-Bilska AT, Johnson ML, Bilski JJ, et al. Wound healing: the role of growth factors. Drugs Today (Barc) 2003;39:787-800. [PubMed: 14668934]

12. Ferrara N, Henzel WJ. Pituitary follicular cells secrete a novel heparin-binding growth factor specific for vascular endothelial cells. Biochem Biophys Res Commun 1989;161:851-8. [PubMed: 2735925]

13. Plouet J, Schilling J, Gospodarowicz D. Isolation and characterization of a newly identified endothelial cell mitogen produced by AtT-20 cells. Embo J 1989;8:3801-6. [PubMed: 2684646] 
14. Gospodarowicz D, Abraham JA, Schilling J. Isolation and characterization of a vascular endothelial cell mitogen produced by pituitary-derived folliculo stellate cells. Proc Natl Acad Sci U S A 1989;86:7311-5. [PubMed: 2798412]

15. Leung DW, Cachianes G, Kuang WJ, Goeddel DV, Ferrara N. Vascular endothelial growth factor is a secreted angiogenic mitogen. Science 1989;246:1306-9. [PubMed: 2479986]

16. Keck PJ, Hauser SD, Krivi G, et al. Vascular permeability factor, an endothelial cell mitogen related to PDGF. Science 1989;246:1309-12. [PubMed: 2479987]

17. Connolly DT, Heuvelman DM, Nelson R, et al. Tumor vascular permeability factor stimulates endothelial cell growth and angiogenesis. J Clin Invest 1989;84:1470-8. [PubMed: 2478587]

18. Yoshida A, Anand-Apte B, Zetter BR. Differential endothelial migration and proliferation to basic fibroblast growth factor and vascular endothelial growth factor. Growth Factors 1996;13:57-64. [PubMed: 8962720]

19. Noiri E, Lee E, Testa J, et al. Podokinesis in endothelial cell migration: role of nitric oxide. Am J Physiol 1998;274:C236-44. [PubMed: 9458733]

20. Senger DR, Galli SJ, Dvorak AM, Perruzzi CA, Harvey VS, Dvorak HF. Tumor cells secrete a vascular permeability factor that promotes accumulation of ascites fluid. Science 1983;219:983-5. [PubMed: 6823562]

21. Senger DR, Connolly DT, Van de Water L, Feder J, Dvorak HF. Purification and NH2-terminal amino acid sequence of guinea pig tumor-secreted vascular permeability factor. Cancer Res 1990;50:17748. [PubMed: 2155059]

22. Brkovic A, Sirois MG. Vascular permeability induced by VEGF family members in vivo: Role of endogenous PAF and NO synthesis. J Cell Biochem. 2006

23. Ferrara N. Molecular and biological properties of vascular endothelial growth factor. J Mol Med 1999;77:527-43. [PubMed: 10494799]

24. Gavard J, Gutkind JS. VEGF controls endothelial-cell permeability by promoting the beta-arrestindependent endocytosis of VE-cadherin. Nat Cell Biol 2006;8:1223-34. [PubMed: 17060906]

25. Griffoen AW, Molema G. Angiogenesis: potentials for pharmacological interventionin the treatment of cancer, cardiovascular diseases, and chronic inflammation. Pharmac Rev 2000;52:237-68.

26. Yamagishi S, Yonekura H, Yamamoto Y, et al. Vascular endothelial growth factor acts as a pericyte mitogen under hypoxic conditions. Lab Invest 1999;79:501-9. [PubMed: 10212003]

27. Stojadinovic OKA, Golinko M, Tomic-Canic M, Brem H. A novel, non-angiogenic mechanism of VEGF: stimulation of keratinocyte and fibroblast migration. Wound Repair and Regeneration 2007:A30.

28. Ladin D. Becaplermin gel (PDGF-BB) as topical wound therapy. Plastic Surgery Educational Foundation DATA Committee. Plast Reconstr Surg 2000;105:1230-1. [PubMed: 10724287]

29. Falanga V. Apligraf treatment of venous ulcers and other chronic wounds. J Dermatol 1998;25:8127. [PubMed: 9990774]

30. Brem H, Balledux J, Sukkarieh T, Carson P, Falanga V. Healing of venous ulcers of long duration with a bilayered living skin substitute: results from a general surgery and dermatology department. Dermatol Surg 2001;27:915-9. [PubMed: 11737123]

31. Brem H, Balledux J, Bloom T, Kerstein MD, Hollier L. Healing of diabetic foot ulcers and pressure ulcers with human skin equivalent: a new paradigm in wound healing. Arch Surg 2000;135:627-34. [PubMed: 10843357]

32. Tischer E, Mitchell R, Hartman T, et al. The human gene for vascular endothelial growth factor. Multiple protein forms are encoded through alternative exon splicing. J Biol Chem 1991;266:1194754. [PubMed: 1711045]

33. Houck KA, Ferrara N, Winer J, Cachianes G, Li B, Leung DW. The vascular endothelial growth factor family: identification of a fourth molecular species and characterization of alternative splicing of RNA. Mol Endocrinol 1991;5:1806-14. [PubMed: 1791831]

34. Houck KA, Leung DW, Rowland AM, Winer J, Ferrara N. Dual regulation of vascular endothelial growth factor bioavailability by genetic and proteolytic mechanisms. J Biol Chem 1992;267:260317. [PubMed: 1464614]

35. Poltorak Z, Cohen T, Sivan R, et al. VEGF145, a secreted vascular endothelial growth factor isoform that binds to extracellular matrix. J Biol Chem 1997;272:7151-8. [PubMed: 9054410] 
36. Maruyama K, Asai J, Ii M, Thorne T, Losordo DW, D’Amore PA. Decreased macrophage number and activation lead to reduced lymphatic vessel formation and contribute to impaired diabetic wound healing. Am J Pathol 2007;170:1178-91. [PubMed: 17392158]

37. Uchida K, Uchida S, Nitta K, Yumura W, Marumo F, Nihei H. Glomerular endothelial cells in culture express and secrete vascular endothelial growth factor. Am J Physiol 1994;266:F81-8. [PubMed: 8304487]

38. Namiki A, Brogi E, Kearney M, et al. Hypoxia induces vascular endothelial growth factor in cultured human endothelial cells. J Biol Chem 1995;270:31189-95. [PubMed: 8537383]

39. Nissen NN, Polverini PJ, Koch AE, Volin MV, Gamelli RL, DiPietro LA. Vascular endothelial growth factor mediates angiogenic activity during the proliferative phase of wound healing. Am J Pathol 1998;152:1445-52. [PubMed: 9626049]

40. Brogi E, Wu T, Namiki A, Isner JM. Indirect angiogenic cytokines upregulate VEGF and bFGF gene expression in vascular smooth muscle cells, whereas hypoxia upregulates VEGF expression only. Circulation 1994;90:649-52. [PubMed: 8044933]

41. Stavri GT, Zachary IC, Baskerville PA, Martin JF, Erusalimsky JD. Basic fibroblast growth factor upregulates the expression of vascular endothelial growth factor in vascular smooth muscle cells. Synergistic interaction with hypoxia. Circulation 1995;92:11-4. [PubMed: 7788904]

42. Banks RE, Forbes MA, Kinsey SE, et al. Release of the angiogenic cytokine vascular endothelial growth factor (VEGF) from platelets: significance for VEGF measurements and cancer biology. $\mathrm{Br}$ J Cancer 1998;77:956-64. [PubMed: 9528841]

43. Gaudry M, Bregerie O, Andrieu V, El Benna J, Pocidalo MA, Hakim J. Intracellular pool of vascular endothelial growth factor in human neutrophils. Blood 1997;90:4153-61. [PubMed: 9354686]

44. Berse B, Brown LF, Van de Water L, Dvorak HF, Senger DR. Vascular permeability factor (vascular endothelial growth factor) gene is expressed differentially in normal tissues, macrophages, and tumors. Mol Biol Cell 1992;3:211-20. [PubMed: 1550962]

45. de Vries C, Escobedo JA, Ueno H, Houck K, Ferrara N, Williams LT. The fms-like tyrosine kinase, a receptor for vascular endothelial growth factor. Science 1992;255:989-91. [PubMed: 1312256]

46. Thomas KA. Vascular endothelial growth factor, a potent and selective angiogenic agent. J Biol Chem 1996;271:603-6. [PubMed: 8557658]

47. Terman BI, Dougher-Vermazen M, Carrion ME, et al. Identification of the KDR tyrosine kinase as a receptor for vascular endothelial cell growth factor. Biochem Biophys Res Commun 1992;187:1579-86. [PubMed: 1417831]

48. Soker S, Fidder H, Neufeld G, Klagsbrun M. Characterization of novel vascular endothelial growth factor (VEGF) receptors on tumor cells that bind VEGF165 via its exon 7-encoded domain. J Biol Chem 1996;271:5761-7. [PubMed: 8621443]

49. Olander JV, Connolly DT, DeLarco JE. Specific binding of vascular permeability factor to endothelial cells. Biochem Biophys Res Commun 1991;175:68-76. [PubMed: 1998521]

50. Peters KG, De Vries C, Williams LT. Vascular endothelial growth factor receptor expression during embryogenesis and tissue repair suggests a role in endothelial differentiation and blood vessel growth. Proc Natl Acad Sci U S A 1993;90:8915-9. [PubMed: 7692439]

51. Breier G, Damert A, Plate KH, Risau W. Angiogenesis in embryos and ischemic diseases. Thromb Haemost 1997;78:678-83. [PubMed: 9198238]

52. Barleon B, Hauser S, Schollmann C, et al. Differential expression of the two VEGF receptors flt and KDR in placenta and vascular endothelial cells. J Cell Biochem 1994;54:56-66. [PubMed: 8126087]

53. Shalaby F, Rossant J, Yamaguchi TP, et al. Failure of blood-island formation and vasculogenesis in Flk-1-deficient mice. Nature 1995;376:62-6. [PubMed: 7596435]

54. Fong GH, Rossant J, Gertsenstein M, Breitman ML. Role of the Flt-1 receptor tyrosine kinase in regulating the assembly of vascular endothelium. Nature 1995;376:66-70. [PubMed: 7596436]

55. Waltenberger J, Claesson-Welsh L, Siegbahn A, Shibuya M, Heldin CH. Different signal transduction properties of KDR and Flt1, two receptors for vascular endothelial growth factor. J Biol Chem 1994;269:26988-95. [PubMed: 7929439]

56. Malavaud B, Tack I, Jonca F, et al. Activation of Flk-1/KDR mediates angiogenesis but not hypotension. Cardiovasc Res 1997;36:276-81. [PubMed: 9463639] 
57. Barleon B, Sozzani S, Zhou D, Weich HA, Mantovani A, Marme D. Migration of human monocytes in response to vascular endothelial growth factor (VEGF) is mediated via the VEGF receptor flt-1. Blood 1996;87:3336-43. [PubMed: 8605350]

58. Wang H, Keiser JA. Vascular endothelial growth factor upregulates the expression of matrix metalloproteinases in vascular smooth muscle cells: role of flt-1. Circ Res 1998;83:832-40. [PubMed: 9776730]

59. Katoh O, Tauchi H, Kawaishi K, Kimura A, Satow Y. Expression of the vascular endothelial growth factor (VEGF) receptor gene, KDR, in hematopoietic cells and inhibitory effect of VEGF on apoptotic cell death caused by ionizing radiation. Cancer Res 1995;55:5687-92. [PubMed: 7585655]

60. Pajusola K, Aprelikova O, Korhonen J, et al. FLT4 receptor tyrosine kinase contains seven immunoglobulin-like loops and is expressed in multiple human tissues and cell lines. Cancer research 1992;52:5738-43. [PubMed: 1327515]

61. Galland F, Karamysheva A, Mattei MG, Rosnet O, Marchetto S, Birnbaum D. Chromosomal localization of FLT4, a novel receptor-type tyrosine kinase gene. Genomics 1992;13:475-8. [PubMed: 1319394]

62. Veikkola T, Jussila L, Makinen T, et al. Signalling via vascular endothelial growth factor receptor-3 is sufficient for lymphangiogenesis in transgenic mice. The EMBO journal 2001;20:1223-31. [PubMed: 11250889]

63. Enholm B, Karpanen T, Jeltsch M, et al. Adenoviral expression of vascular endothelial growth factorC induces lymphangiogenesis in the skin. Circulation research 2001;88:623-9. [PubMed: 11282897]

64. Folkman, J.; Brem, H. Angiogenesis and inflammation. In: Gallin, J.; Goldstein, I.; Snyderman, R., editors. Inflammation: Basic Principles and Clinical Correlates. Vol. 2. New York: Raven Press; 1992. p. 821-39.

65. Murohara T, Horowitz JR, Silver M, et al. Vascular endothelial growth factor/vascular permeability factor enhances vascular permeability via nitric oxide and prostacyclin. Circulation 1998;97:99-107. [PubMed: 9443437]

66. Ku DD, Zaleski JK, Liu S, Brock TA. Vascular endothelial growth factor induces EDRF-dependent relaxation in coronary arteries. Am J Physiol 1993;265:H586-92. [PubMed: 8368362]

67. van der Zee R, Murohara T, Luo Z, et al. Vascular endothelial growth factor/vascular permeability factor augments nitric oxide release from quiescent rabbit and human vascular endothelium. Circulation 1997;95:1030-7. [PubMed: 9054767]

68. Li J, Hampton T, Morgan JP, Simons M. Stretch-induced VEGF expression in the heart. J Clin Invest 1997;100:18-24. [PubMed: 9202052]

69. Brock TA, Dvorak HF, Senger DR. Tumor-secreted vascular permeability factor increases cytosolic Ca2+ and von Willebrand factor release in human endothelial cells. Am J Pathol 1991;138:213-21. [PubMed: 1987767]

70. Unemori EN, Ferrara N, Bauer EA, Amento EP. Vascular endothelial growth factor induces interstitial collagenase expression in human endothelial cells. J Cell Physiol 1992;153:557-62. [PubMed: 1447317]

71. Pepper MS, Ferrara N, Orci L, Montesano R. Vascular endothelial growth factor (VEGF) induces plasminogen activators and plasminogen activator inhibitor-1 in microvascular endothelial cells. Biochem Biophys Res Commun 1991;181:902-6. [PubMed: 1755866]

72. Yebra M, Parry GC, Stromblad S, et al. Requirement of receptor-bound urokinase-type plasminogen activator for integrin alphavbeta5-directed cell migration. J Biol Chem 1996;271:29393-9. [PubMed: 8910604]

73. Suzuma K, Takagi H, Otani A, Honda Y. Hypoxia and vascular endothelial growth factor stimulate angiogenic integrin expression in bovine retinal microvascular endothelial cells. Invest Ophthalmol Vis Sci 1998;39:1028-35. [PubMed: 9579483]

74. Senger DR, Ledbetter SR, Claffey KP, Papadopoulos-Sergiou A, Peruzzi CA, Detmar M. Stimulation of endothelial cell migration by vascular permeability factor/vascular endothelial growth factor through cooperative mechanisms involving the alphavbeta3 integrin, osteopontin, and thrombin. Am J Pathol 1996;149:293-305. [PubMed: 8686754] 
75. Morbidelli L, Chang CH, Douglas JG, Granger HJ, Ledda F, Ziche M. Nitric oxide mediates mitogenic effect of VEGF on coronary venular endothelium. Am J Physiol 1996;270:H411-5. [PubMed: 8769777]

76. Pepper MS, Ferrara N, Orci L, Montesano R. Potent synergism between vascular endothelial growth factor and basic fibroblast growth factor in the induction of angiogenesis in vitro. Biochem Biophys Res Commun 1992;189:824-31. [PubMed: 1281999]

77. Goto F, Goto K, Weindel K, Folkman J. Synergistic effects of vascular endothelial growth factor and basic fibroblast growth factor on the proliferation and cord formation of bovine capillary endothelial cells within collagen gels. Lab Invest 1993;69:508-17. [PubMed: 8246443]

78. Watanabe Y, Lee SW, Detmar M, Ajioka I, Dvorak HF. Vascular permeability factor/vascular endothelial growth factor (VPF/VEGF) delays and induces escape from senescence in human dermal microvascular endothelial cells. Oncogene 1997;14:2025-32. [PubMed: 9160882]

79. Gerber HP, McMurtrey A, Kowalski J, et al. Vascular endothelial growth factor regulates endothelial cell survival through the phosphatidylinositol 3'-kinase/Akt signal transduction pathway. Requirement for Flk-1/KDR activation. J Biol Chem 1998;273:30336-43. [PubMed: 9804796]

80. Spyridopoulos I, Brogi E, Kearney M, et al. Vascular endothelial growth factor inhibits endothelial cell apoptosis induced by tumor necrosis factor-alpha: balance between growth and death signals. $\mathrm{J}$ Mol Cell Cardiol 1997;29:1321-30. [PubMed: 9201618]

81. Watanabe Y, Dvorak HF. Vascular permeability factor/vascular endothelial growth factor inhibits anchorage-disruption-induced apoptosis in microvessel endothelial cells by inducing scaffold formation. Exp Cell Res 1997;233:340-9. [PubMed: 9194496]

82. Abid MR, Shih SC, Otu HH, et al. A novel class of vascular endothelial growth factor-responsive genes that require forkhead activity for expression. J Biol Chem 2006;281:35544-53. [PubMed: 16980307]

83. Vinci MC, Visentin B, Cusinato F, Nardelli GB, Trevisi L, Luciani S. Effect of vascular endothelial growth factor and epidermal growth factor on iatrogenic apoptosis in human endothelial cells. Biochem Pharmacol 2004;67:277-84. [PubMed: 14698040]

84. Abid MR, Guo S, Minami T, et al. Vascular endothelial growth factor activates PI3K/Akt/forkhead signaling in endothelial cells. Arterioscler Thromb Vasc Biol 2004;24:294-300. [PubMed: 14656735]

85. Zheng J, Wen Y, Song Y, Wang K, Chen DB, Magness RR. Activation of multiple signaling pathways is critical for fibroblast growth factor 2- and vascular endothelial growth factor-stimulated ovine fetoplacental endothelial cell proliferation. Biol Reprod 2008;78:143-50. [PubMed: 17901071]

86. Gratton JP, Morales-Ruiz M, Kureishi Y, Fulton D, Walsh K, Sessa WC. Akt down-regulation of p38 signaling provides a novel mechanism of vascular endothelial growth factor-mediated cytoprotection in endothelial cells. J Biol Chem 2001;276:30359-65. [PubMed: 11387313]

87. Brem, H.; Folkman, J. Angiogenesis and basic fibroblast growth factor during wound healing. In: Friedlander, GE.; Lane, JM., editors. Bone Formation and Repair. Rosemont: American Academy of Orthopedic Surgeons; 1994. p. 213-22.

88. Brem H, Erlich P, Tsakayannis D, et al. Delay of Wound Healing by the Angiogenesis Inhibitor TNP-470. Surgical Forum 1997;48:714-6.

89. McGrath MH, Emery JM 3rd. The effect of inhibition of angiogenesis in granulation tissue on wound healing and the fibroblast. Ann Plast Surg 1985;15:105-22. [PubMed: 4091464]

90. Brem H, Tsakayannis D, Folkman J. Time dependent suppression of wound healing with the angiogenesis inhibitor, AGM 1470. J Cell Biol 1991;115:403a.

91. Mohle R, Green D, Moore MA, Nachman RL, Rafii S. Constitutive production and thrombin-induced release of vascular endothelial growth factor by human megakaryocytes and platelets. Proc Natl Acad Sci U S A 1997;94:663-8. [PubMed: 9012841]

92. Leibovich SJ, Polverini PJ, Shepard HM, Wiseman DM, Shively V, Nuseir N. Macrophage-induced angiogenesis is mediated by tumour necrosis factor-alpha. Nature 1987;329:630-2. [PubMed: 2443857]

93. Frank S, Hubner G, Breier G, Longaker MT, Greenhalgh DG, Werner S. Regulation of vascular endothelial growth factor expression in cultured keratinocytes. Implications for normal and impaired wound healing. J Biol Chem 1995;270:12607-13. [PubMed: 7759509] 
94. Takahashi M, Kawabe T, Ogura K, et al. Expression of vascular endothelial growth factor at the human gastric ulcer margin and in cultured gastric fibroblasts: a new angiogenic factor for gastric ulcer healing. Biochem Biophys Res Commun 1997;234:493-8. [PubMed: 9177300]

95. Niiinikoski J, Heughan C, Hunt T. Oxygen and carbon dioxide tensions in experimental wounds. Surg Gynecol Obstet 1971;133:1003-7. [PubMed: 5117384]

96. Silver IA. The measurement of oxygen tension in healing tissue. Progr Respir Res 1969;3:124-35.

97. Detmar M, Brown LF, Berse B, et al. Hypoxia regulates the expression of vascular permeability factor/vascular endothelial growth factor (VPF/VEGF) and its receptors in human skin. J Invest Dermatol 1997;108:263-8. [PubMed: 9036922]

98. Levy AP, Levy NS, Loscalzo J, et al. Regulation of vascular endothelial growth factor in cardiac myocytes. Circ Res 1995;76:758-66. [PubMed: 7728992]

99. Shweiki D, Itin A, Soffer D, Keshet E. Vascular endothelial growth factor induced by hypoxia may mediate hypoxia-initiated angiogenesis. Nature 1992;359:843-5. [PubMed: 1279431]

100. Hashimoto E, Kage K, Ogita T, Nakaoka T, Matsuoka R, Kira Y. Adenosine as an endogenous mediator of hypoxia for induction of vascular endothelial growth factor mRNA in U-937 cells. Biochem Biophys Res Commun 1994;204:318-24. [PubMed: 7945378]

101. Takagi H, King GL, Ferrara N, Aiello LP. Hypoxia regulates vascular endothelial growth factor receptor KDR/Flk gene expression through adenosine A2 receptors in retinal capillary endothelial cells. Invest Ophthalmol Vis Sci 1996;37:1311-21. [PubMed: 8641834]

102. Levy AP, Levy NS, Goldberg MA. Post-transcriptional regulation of vascular endothelial growth factor by hypoxia. J Biol Chem 1996;271:2746-53. [PubMed: 8576250]

103. Levy AP, Levy NS, Wegner S, Goldberg MA. Transcriptional regulation of the rat vascular endothelial growth factor gene by hypoxia. J Biol Chem 1995;270:13333-40. [PubMed: 7768934]

104. Stein I, Neeman M, Shweiki D, Itin A, Keshet E. Stabilization of vascular endothelial growth factor mRNA by hypoxia and hypoglycemia and coregulation with other ischemia-induced genes. Mol Cell Biol 1995;15:5363-8. [PubMed: 7565686]

105. Elson DA, Ryan HE, Snow JW, Johnson R, Arbeit JM. Coordinate up-regulation of hypoxia inducible factor (HIF)-1alpha and HIF-1 target genes during multi-stage epidermal carcinogenesis and wound healing. Cancer Res 2000;60:6189-95. [PubMed: 11085544]

106. Mace KA, Yu DH, Paydar KZ, Boudreau N, Young DM. Sustained expression of Hif-1alpha in the diabetic environment promotes angiogenesis and cutaneous wound repair. Wound Repair Regen 2007;15:636-45. [PubMed: 17971009]

107. Knighton DR, Silver IA, Hunt TK. Regulation of wound-healing angiogenesis-effect of oxygen gradients and inspired oxygen concentration. Surgery 1981;90:262-70. [PubMed: 6166996]

108. Brown LF, Yeo KT, Berse B, et al. Expression of vascular permeability factor (vascular endothelial growth factor) by epidermal keratinocytes during wound healing. J Exp Med 1992;176:1375-9. [PubMed: 1402682]

109. Shukla A, Dubey MP, Srivastava R, Srivastava BS. Differential expression of proteins during healing of cutaneous wounds in experimental normal and chronic models. Biochem Biophys Res Commun 1998;244:434-9. [PubMed: 9514941]

110. Howard EW, Soo C, Hunter S, Zhang X, Shaw WW, Longaker MT. Differences in MMP and TIMP gene expression during wound repair. Surg Forum 1997;48:688-91.

111. Nissen NN, Polverini PJ, Gamelli RL, DiPietro LA. Basic fibroblast growth factor mediates angiogenic activity in early surgical wounds. Surgery 1996;119:457-65. [PubMed: 8644013]

112. Bikfalvi A, Klein S, Pintucci G, Rifkin DB. Biological roles of fibroblast growth factor-2. Endocr Rev 1997;18:26-45. [PubMed: 9034785]

113. Brem H, Shing Y, Watanabe Y, et al. Temporal expression of basic fibroblast growth factor during wound healing. Surg Forum 1992;43:664-7.

114. Seghezzi G, Patel S, Ren CJ, et al. Fibroblast growth factor-2 (FGF-2) induces vascular endothelial growth factor (VEGF) expression in the endothelial cells of forming capillaries: an autocrine mechanism contributing to angiogenesis. J Cell Biol 1998;141:1659-73. [PubMed: 9647657]

115. Mandriota SJ, Pepper MS. Vascular endothelial growth factor-induced in vitro angiogenesis and plasminogen activator expression are dependent on endogenous basic fibroblast growth factor. J Cell Sci 1997;110 ( Pt 18):2293-302. [PubMed: 9378778] 
116. Clark RA, Tonnesen MG, Gailit J, Cheresh DA. Transient functional expression of alphaVbeta 3 on vascular cells during wound repair. Am J Pathol 1996;148:1407-21. [PubMed: 8623913]

117. Christofidou-Solomidou M, Bridges M, Murphy GF, Albelda SM, DeLisser HM. Expression and function of endothelial cell alpha $v$ integrin receptors in wound-induced human angiogenesis in human skin/SCID mice chimeras. Am J Pathol 1997;151:975-83. [PubMed: 9327731]

118. Isner JM, Pieczek A, Schainfeld R, et al. Clinical evidence of angiogenesis after arterial gene transfer of phVEGF165 in patient with ischaemic limb. Lancet 1996;348:370-4. [PubMed: 8709735]

119. Baumgartner I, Pieczek A, Manor O, et al. Constitutive expression of phVEGF165 after intramuscular gene transfer promotes collateral vessel development in patients with critical limb ischemia. Circulation 1998;97:1114-23. [PubMed: 9537336]

120. Isner JM, Baumgartner I, Rauh G, et al. Treatment of thromboangiitis obliterans (Buerger's disease) by intramuscular gene transfer of vascular endothelial growth factor: preliminary clinical results. J Vasc Surg 1998;28:964-73. [PubMed: 9845647]discussion 73-5

121. Losordo DW, Vale PR, Symes JF, et al. Gene therapy for myocardial angiogenesis: initial clinical results with direct myocardial injection of phVEGF165 as sole therapy for myocardial ischemia. Circulation 1998;98:2800-4. [PubMed: 9860779]

122. Laitinen M, Hartikainen J, Hiltunen MO, et al. Catheter-mediated vascular endothelial growth factor gene transfer to human coronary arteries after angioplasty. Hum Gene Ther 2000;11:263-70. [PubMed: 10680840]

123. Rosengart TK, Lee LY, Patel SR, et al. Angiogenesis gene therapy: phase I assessment of direct intramyocardial administration of an adenovirus vector expressing VEGF121 cDNA to individuals with clinically significant severe coronary artery disease. Circulation 1999;100:468-74. [PubMed: 10430759]

124. Rosengart TK, Lee LY, Patel SR, et al. Six-month assessment of a phase I trial of angiogenic gene therapy for the treatment of coronary artery disease using direct intramyocardial administration of an adenovirus vector expressing the VEGF121 cDNA. Ann Surg 1999;230:466-70. [PubMed: 10522716]discussion 70-2

125. Olerud JE, Odland GF, Burgess EM, Wyss CR, Fisher LD, Matsen FA 3rd. A model for the study of wounds in normal elderly adults and patients with peripheral vascular disease or diabetes mellitus. J Surg Res 1995;59:349-60. [PubMed: 7643593]

126. Wyss CR, Matsen FA 3rd, Simmons CW, Burgess EM. Transcutaneous oxygen tension measurements on limbs of diabetic and nondiabetic patients with peripheral vascular disease. Surgery 1984;95:339-46. [PubMed: 6701790]

127. Allen DB, Maguire JJ, Mahdavian M, et al. Wound hypoxia and acidosis limit neutrophil bacterial killing mechanisms. Arch Surg 1997;132:991-6. [PubMed: 9301612]

128. Hopf HW, Hunt TK, West JM, et al. Wound tissue oxygen tension predicts the risk of wound infection in surgical patients. Arch Surg 1997;132:997-1004. [PubMed: 9301613]discussion 5

129. Pecoraro RE, Ahroni JH, Boyko EJ, Stensel VL. Chronology and determinants of tissue repair in diabetic lower-extremity ulcers. Diabetes 1991;40:1305-13. [PubMed: 1936593]

130. Marin P, Andersson B, Krotkiewski M, Bjorntorp P. Muscle fiber composition and capillary density in women and men with NIDDM. Diabetes Care 1994;17:382-6. [PubMed: 8062604]

131. Brem H, Tomic-Canic M. Cellular and molecular basis of wound healing in diabetes. J Clin Invest 2007;117:1219-22. [PubMed: 17476353]

132. Stehouwer CD, Lambert J, Donker AJ, van Hinsbergh VW. Endothelial dysfunction and pathogenesis of diabetic angiopathy. Cardiovasc Res 1997;34:55-68. [PubMed: 9217873]

133. Rivard A, Silver M, Chen D, et al. Rescue of diabetes-related impairment of angiogenesis by intramuscular gene therapy with adeno-VEGF. Am J Pathol 1999;154:355-63. [PubMed: 10027394]

134. Sone H, Kawakami Y, Okuda Y, et al. Vascular endothelial growth factor is induced by long-term high glucose concentration and up-regulated by acute glucose deprivation in cultured bovine retinal pigmented epithelial cells. Biochem Biophys Res Commun 1996;221:193-8. [PubMed: 8660335]

135. Albertson S, Hummel RP 3rd, Breeden M, Greenhalgh DG. PDGF and FGF reverse the healing impairment in protein-malnourished diabetic mice. Surgery 1993;114:368-72. [PubMed: 8342137] discussion 72-3 
136. VEGF enhances angiogenic response in experimental wounds as measured by tensile properties of the wound, increased epithelialization, and decreased time to closure. Wounds. 2007 [Accessed 3/31/2008]. at http://www.woundsresearch.com/article/6976.)

137. Smiell JM, Wieman TJ, Steed DL, Perry BH, Sampson AR, Schwab BH. Efficacy and safety of becaplermin (recombinant human platelet-derived growth factor-BB) in patients with nonhealing, lower extremity diabetic ulcers: a combined analysis of four randomized studies. Wound Repair Regen 1999;7:335-46. [PubMed: 10564562]

138. Dormandy A. Pathophysiology of venous leg ulceration. Int J Microcirc Clin Exp 1997;17 (Suppl 1):2-5. [PubMed: 9477037]

139. Mirshahi S, Soria J, Mirshahi M, et al. Expression of elastase and fibrin in venous leg ulcer biopsies: a pilot study of pentoxifylline versus placebo. J Cardiovasc Pharmacol 1995;25 (Suppl 2):S101-5. [PubMed: 8699846]

140. Vaalamo M, Weckroth M, Puolakkainen P, et al. Patterns of matrix metalloproteinase and TIMP-1 expression in chronic and normally healing human cutaneous wounds. Br J Dermatol 1996;135:529. [PubMed: 8776359]

141. Vaalamo M, Leivo T, Saarialho-Kere U. Differential expression of tissue inhibitors of metalloproteinases (TIMP-1, -2, -3, and -4) in normal and aberrant wound healing. Hum Pathol 1999;30:795-802. [PubMed: 10414498]

142. Barone EJ, Yager DR, Pozez AL, et al. Interleukin-1alpha and collagenase activity are elevated in chronic wounds. Plast Reconstr Surg 1998;102:1023-7. [PubMed: 9734419]discussion 8-9

143. Shoab SS, Scurr JH, Coleridge-Smith PD. Increased plasma vascular endothelial growth factor among patients with chronic venous disease. J Vasc Surg 1998;28:535-40. [PubMed: 9737465]

144. Peschen M, Grenz H, Brand-Saberi B, et al. Increased expression of platelet-derived growth factor receptor alpha and beta and vascular endothelial growth factor in the skin of patients with chronic venous insufficiency. Arch Dermatol Res 1998;290:291-7. [PubMed: 9705159]

145. Schubert V. Hypotension as a risk factor for the development of pressure sores in elderly subjects. Age Ageing 1991;20:255-61. [PubMed: 1927731]

146. Schubert V, Fagrell B. Local skin pressure and its effects on skin microcirculation as evaluated by laser-Doppler fluxmetry. Clin Physiol 1989;9:535-45. [PubMed: 2689062]

147. Schubert V, Schubert PA, Breit G, Intaglietta M. Analysis of arterial flowmotion in spinal cord injured and elderly subjects in an area at risk for the development of pressure sores. Paraplegia 1995;33:387-97. [PubMed: 7478728]

148. Mawson AR, Siddiqui FH, Biundo JJ Jr. Enhancing host resistance to pressure ulcers: a new approach to prevention. Prev Med 1993;22:433-50. [PubMed: 8327423]

149. Robson MC, Phillips LG, Lawrence WT, et al. The safety and effect of topically applied recombinant basic fibroblast growth factor on the healing of chronic pressure sores. Ann Surg 1992;216:401-6. [PubMed: 1417189]discussion 6-8

150. Robson MC, Hill DP, Smith PD, et al. Sequential cytokine therapy for pressure ulcers: clinical and mechanistic response. Ann Surg 2000;231:600-11. [PubMed: 10749622] 

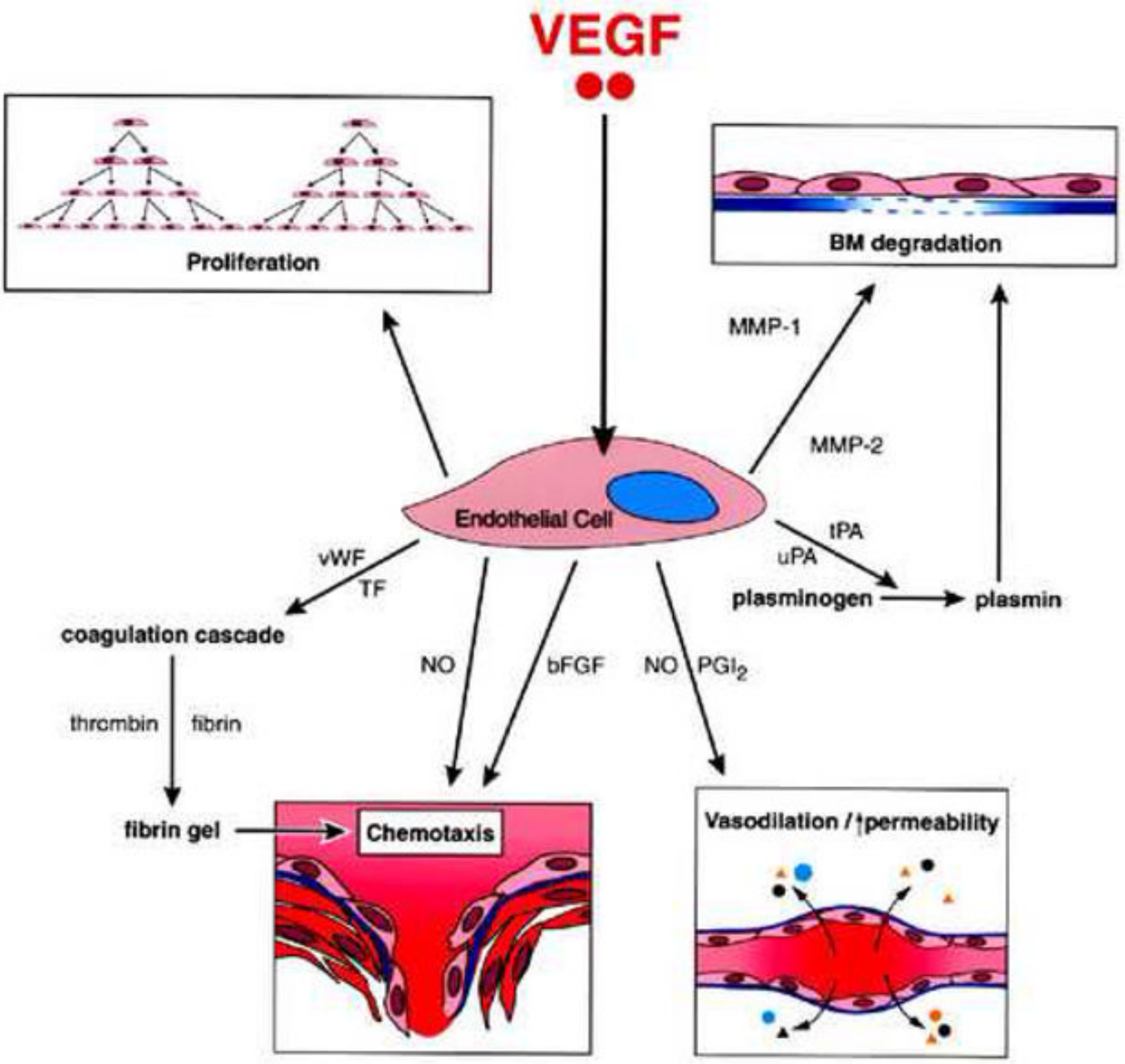

Figure 1.

Demonstration of VEGF's potential role in a healing wound. By stimulating the endothelial cell, multiple phases of the angiogenic cascade are enhanced. This figure highlights the multiple synergistic stimulants to angiogenesis that may be generated if VEGF is administered to a wound. 


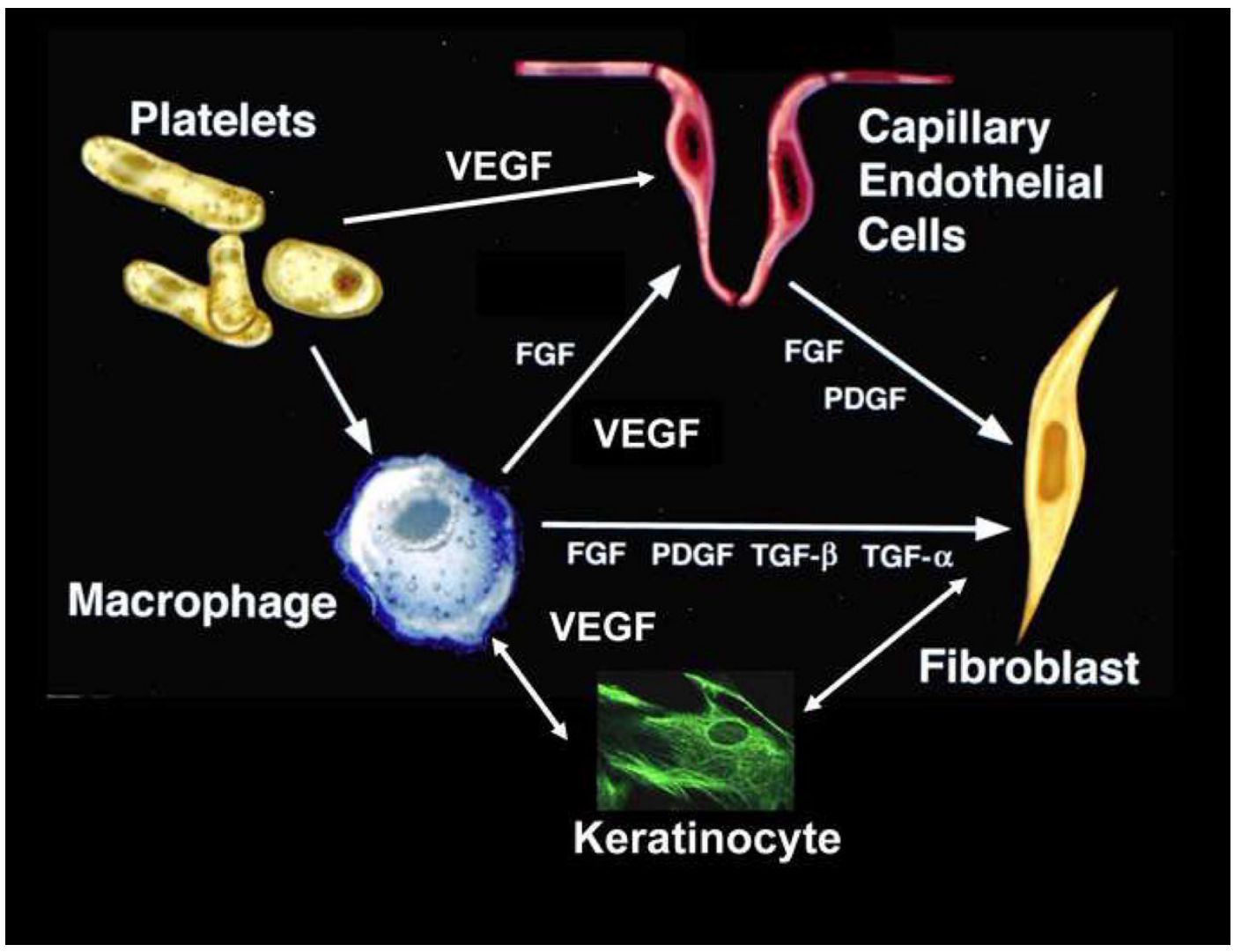

Figure 2. VEGF and Cellular Basis of Healing

Note the multiple roles that endogenous cells play in producing VEGF in the local wound environment. Platlets arrive first on Day "0" of wounding, followed by a peak of macrophages at Day 2. Endothelial cells begin to migrate at Day 2 and new capillary endothelium can be seen between Day's 3-4. By Day 5, new collagen is produced from fibroblasts. The initial cell that releases VEGF are platelets which enter the wound after debridement. In addition, macrophages release VEGF which stimulate endothelial cells to proliferate and migrate. VEGF has been shown to stimulate keratinocyte migration and collagen production via fibroblasts. VEGF secretion also induces release of other growth factors which further stimulate healing. 
Table 1

Clinical conditions associated with chronic wounds

- Obesity

- Chemotherapy

- $\quad$ Steroid use

- Infection

- Radiation

- Diabetes mellitus

- Venous insufficiency

- Arterial insufficiency

- Pressure

- $\quad$ Sickle cell disease 
Table 2

Inflammatory cytokines and growth factors which induce VEGF expression and/or release from a variety of cell types.

\begin{tabular}{|c|c|}
\hline Cytokine/Growth Factor & Target Cell(s) \\
\hline $\mathrm{TNF}-\alpha^{x}$ & keratinocytes, fibroblasts, neutrophils \\
\hline TGF- $\beta^{v i i i}$ & keratinocytes \\
\hline TGF- $\beta^{i x}$ & keratinocytes, arterial smooth muscle \\
\hline $\mathrm{EGF}^{i i}$ & keratinocytes, arterial smooth muscle \\
\hline $\mathrm{KGF}^{v}$ & keratinocytes, arterial smooth muscle \\
\hline $\mathrm{bFGF}^{i}$ & aortic smooth muscle \\
\hline $\mathrm{PGE}_{1} / \mathrm{PGE}_{2} v i i$ & osteoblasts \\
\hline $\mathrm{PDGF}_{-\mathrm{BB}}{ }^{v i}$ & arterial smooth muscle \\
\hline $\mathrm{IL}-1 \beta^{i i i}$ & aortic smooth muscle \\
\hline IL-6 $6^{i v}$ & skeletal muscle myoblasts \\
\hline
\end{tabular}

$i_{\text {basic fibroblast growth factor; }}$

${ }^{i i}$ epidermal growth factor;

${ }^{i i i}$ interleukin-1 $\beta$;

$i v_{\text {interleukin-6; }}$

$v_{\text {keratinocyte growth factor; }}$

$v i$ platelet derived growth factor-BB;

vii prostaglandin E1/E2;

viii ${ }_{\text {transforming growth factor } \beta}$

$i x$ transforming growth factor $\beta$;

$x_{\text {tumor necrosis factor- } \alpha}$ 